\title{
Preliminary Analysis of Solar Cell Interconnections Welding Parameters Using Design of Experiments for Future Optimization
}

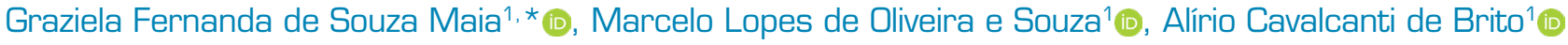 \\ 1. Instituto Nacional de Pesquisas Espaciais - Curso Engenharia e Tecnologia Espaciais - Engenharia e Gerenciamento de Sistemas \\ Espaciais - São José dos Campos/SP - Brazil.
}

*Correspondence author: graziela.fernanda.souza@gmail.com

\begin{abstract}
One of the processes that determine the reliability of solar panels used in space applications is the welding of interconnections between two adjacent solar cells. This process has various technologies, sequences and activities that have various characteristics, factors and parameters. Their combinations and values allow countless possibilities, making their adjustments time consuming, costly and exhausting. One way of abbreviating this, achieving competitiveness and meeting the needs of stakeholders is through the Analysis and Design of Experiments. This technique helps in optimizing the best adjustments to obtain the expected results. Thus, this paper presents a preliminary analysis of the parameters and their interactions of the welding process (by parallel-gap resistance welding) of interconnections between solar cells using design of experiments. In this welding process, the cell undergoes a certain level of degradation. For this reason, it is important to determine which process parameters are important and their proper levels, without big cell degradation. The result of this analysis can be used in the future to optimize the welding process meeting the design requirements for reliability and performance.
\end{abstract}

Keywords: Parallel-gap resistance welding; Solar cells; Experiment design; Reliability.

\section{INTRODUCTION}

Complex and/or highly integrated systems such as satellites, launchers, airplanes and automobiles are required to assess their reliability throughout their life cycle. Predicting the reliability of equipment used in the space sector has become more elaborate and difficult as these space systems are becoming increasingly complex and/or highly integrated (Santos et al. 2019).

The artificial satellites operate under severe conditions imposed by the space environment and in general or are nonrepaired systems in the space during their operational phase. Among the components of the subsystems that make up the satellite, solar panels suffer the most from the severity of the operating environment, for example space debris, temperature cycling or radiation and others (Baruel 2012).

According to Vaz (1999), solar panels have the function of generating the onboard energy necessary to keep operational all subsystems that integrate the satellite, within the specified consumption ranges during all phases of the mission, the useful life and orbital conditions for which it was designed. The solar panel is composed of solar cells, arranged in columns and rows.

Received: Feb. 10, 2020 | Accepted: Oct. 05, 2020

Section Editor: André Luis da Silva

Peer Review History: This is a peer reviewed version of selected paper presented at the $2^{\circ}$ Congresso Aeroespacial Brasileiro occurred in 16 -19 September of 2019 at Universidade Federal de Santa Maria, Santa Maria/RS, Brazil. 
In general, solar cells are the primary generating source of energy for the satellite to be in operation in space. Each of these cells has the function of generating a small amount of electrical energy; therefore, it is up to the project team to determine the number of solar cells required in a solar panel, to supply the necessary energy to the satellite during its useful life (Baruel 2012).

One of the critical processes in the manufacturing of solar panels is the process of welding the interconnectors in the solar cells. The interconnector is the element responsible for conducting the current from one cell to the next and, at the end of a series of solar cells, making the energy available to a terminal or interconnection point (Rauschenbach 1980; Vaz and Vaz 2007).

One of the processes that determine the reliability of solar panels used in space applications is the welding of the interconnections between two adjacent solar cells (Maia et al. 2019). This process has several technologies, sequences and activities that have several characteristics, factors and parameters. The importance and values of these allow for numerous combinations, making their adjustments time-consuming, costly and exhaustive. One way to shorten this, achieve competitiveness and meet the needs of stakeholders is through the Analysis and Design of Experiments. This technique helps in the optimization of the best adjustments to obtain the expected results. Therefore, from the point of view of reliability, one of the main concerns of solar panel manufacturers is the quality of the solder in the interconnections of the cells (Maia et al. 2019).

O'Connor and Kleyner (2012) mention that one of the critical processes for reliability of electronic components is the welding process involved in the manufacturing of these items, as there is a high number of failures attributed to fatigue and cracks that occur in the weld joints.

Thus, one way to obtain increased reliability is through a complete analysis of the process and through the realization of a design of welding experiments. With these two quality tools, it is intended to obtain the optimization of the welding process.

Therefore, this work aims to present an analysis of the welding process (parallel-gap resistance welding) of interconnections between solar cells by analysis and design of experiments. The experimental data used in this work were obtained through a database of welding process of interconnections in solar cells. With the results of this work, the following benefits can be obtained: (1) to improve and optimize the process involved in the manufacturing of solar panels; (2) provide data about the process to the Product Engineering Group at the National Institute for Space Research (INPE); and (3) increase the performance and service life of solar panels.

\section{BASIC CONCEPTS}

This section presents the basic concepts for reading and understanding the article.

\section{Welding Process}

The welding process consists in a fabrication technique using two or more metal parts there are joined to form a single piece when one-part fabrication is expensive or unfavorable. During welding process a filler metal may be used or not to facilitate the joining materials. A variety of welding methods exists, including arc and gas welding, as well as brazing and soldering (Callister Junior 2008).

Resistance spot welding (RSW) is an important metal joining process and widely used in sheet metal fabrication. There were lot of applications in the field of, rail coach manufacturing, aerospace and nuclear sectors, electric and electronic industries and automobile industries.

Parallel-gap resistance welding process consists of a pair of electrodes spaced at a predetermined distance that come into contact with the part (for example solar cell interconnector). In this process, the electric current flows through the electrodes and interconnection of the solar cell. The heat generated in the resistance offered by the workpiece raises the temperature of the workpiece to be welded to the welding temperature (melting point or above). The pressure exerted by the electrodes on the workpiece contributes for the joining (Steinmeier 2010; Rauschenbach 1980).

For welding solar cells interconnections, the parallel-gap resistance welding process, presented at Fig. 1, is used. According to Rauschenbach (1980), this is the unique and practical welding process for solar cell interconnections. 


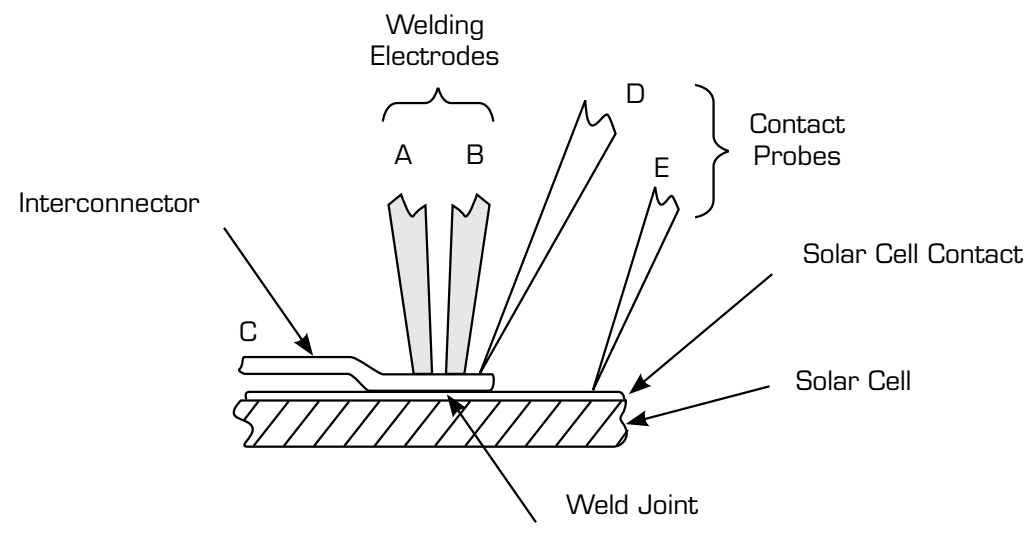

Figure 1. Parallel-gap resistance welding process. Adapted from: Rauschenbach (1980).

\section{Welding Parameters}

The welding parameters (each with a certain value and an appropriate combination between them) establish the conditions that produce the welding process, making possible the joining of the materials. According to Aures (2006), the correct values determine the welding quality.

According to An et al. (2014) and Avila and Bracarense (2017), the main parameters to control and optimize the resistance spot welding are welding current, electrode force and welding time.

The electrical resistance of the part involved in the welding process is extremely important because it is responsible for the Joule effect, but it is not considered a welding parameter (Aures 2006).

Table 1 presents the results of literature survey of most significant parameters in an analysis of the spot resistance welding process, using different statistics techniques to analysis these parameters. Table 1 served as a guide to verify if the chosen parameters were in accordance with industrial and academic practices.

Table 1. Literature survey of parameters and response variable. Source: Maia et al. (2019)

\begin{tabular}{|c|c|c|c|c|c|}
\hline \multirow{2}{*}{$\begin{array}{c}\text { Authors (year) } \\
\text { Atashparva and Hamedi (2018) }\end{array}$} & \multicolumn{3}{|c|}{ Parameters considered } & \multicolumn{2}{|c|}{ Response variable } \\
\hline & Welding Current Welding Time & Electrode force & - & Pull test & $\begin{array}{l}\text { Height and } \\
\text { nugget } \\
\text { diameter }\end{array}$ \\
\hline Amaral et al. (2018) & Welding Current Welding Time & Electrode force & - & Pull test & - \\
\hline Liu [2017] & Welding Current & Electrode force & - & Pull test & - \\
\hline Avila and Bracarense (2017) & Welding Current Welding Time & - & - & Torsion test & - \\
\hline Valera et al. (2017) & Welding Current Welding Time & - & - & Pull test & - \\
\hline Yue et al. (2016) & Welding Current Welding Time & Electrode force & - & Pull test & $\begin{array}{c}\text { Activation } \\
\text { energy }\end{array}$ \\
\hline Abrahão et al. (2015) & Welding Current Welding Time & Electrode force & - & Pull test & - \\
\hline An et al. (2014) & Welding Current Welding Time & Electrode force & - & Pull test & - \\
\hline Souza et al. (2013) & Welding Current Welding Time & Electrode force & - & Pull test & - \\
\hline Muhammad et al. (2012) & Welding Current Welding Time & - & Hold time & Width of HAZ* & $\begin{array}{l}\text { Nugget } \\
\text { Radius }\end{array}$ \\
\hline Maciel Junior [2011] & Welding Current Welding Time & Electrode force & $\begin{array}{l}\text { Time before } \\
\text { electrode } \\
\text { pressure }\end{array}$ & Pull test & - \\
\hline Kim et al. (2007) & Welding Current Welding Time & Electrode force & - & Indentation & $\begin{array}{l}\text { Shear } \\
\text { strength }\end{array}$ \\
\hline
\end{tabular}

Legend: ${ }^{\star} \mathrm{HAZ}$ - Heat affected zone. 
Based on the survey presented in Table 1, the following parameters to be considered for this work will be analyzed: welding voltage, electrode force, welding time and charge involved in the process. The response variable to evaluate the welding joint will be the pull test results.

\section{Welding Current}

In this type of welding, both direct current (DC) and alternating current (AC) can be used. In this work, DC was used. The intensity of the welding current is responsible for the heating of the welded area (Maciel Junior 2011), as the temperature increases, fusion of overlapping materials occurs.

This parameter has a suitable value between a minimum and maximum limit that depends on the material of the parts, the thickness, and the contact area between the electrodes and the part to be welded (Santos 2013).

According to Santos (2013), a welding current below the minimum limit does not achieve adequate heating and melting in the welded joint region. On the other hand, a current higher than the upper limit causes an unnecessary increase in the heat affected zone (HAZ) by heat, as well as overheating of the weld region, which can lead to plastic deformation of the parts to be welded and excessive electrode penetration with corresponding damage.

\section{Welding Time}

Welding time is the duration of welding current distribution to produce the welding point. A very short welding time requires a higher welding current in order to achieve the necessary heat to melt the material (Aures 2006). Short welding time does not melt the material, and it does not produce a good quality welding, which makes the correct control of the welding time critical.

In contrast, the longer welding time can expel the liquid, reducing the joint cross section and resulting in a weak and discontinuous weld, as well as overheating the base metal causing it to boil generating gaseous porosity and heat loss through electrodes and parts involved in welding, resulting in defective weld spots (Miller 2010; Carneiro and Barbosa 2015).

\section{Electrode Force}

Electrode force has the purpose of press and join the parts that are involved in the welding process, by means of pressure before, during and after supplying the welding current (Aures 2006).

The electrode force on the part should not be excessive because the greater the force, the lower the contact resistance, generating insufficient heat for welding.

An excess pressure of the electrode in the part to be welded can cause the weld fracture, wear of the work pieces due to the penetration of the electrodes, deformation of the electrodes (Dias 2011) and, in the case of solar cells, damage, cracks and breakage because they are fragile components.

\section{Failures in Solar Cells Interconnections}

In the manufacturing process of solar panels, solar cells are connected to each other by welding the interconnector (in the form of metal strips or wires) into each of the cells, forming the solar modules. The welding process of interconnectors in solar cells is considered a critical step in the manufacture of solar panels (Gierth et al. 2012; Wiese et al. 2010).

One of the considerable threats to the integrity of welded joints is failure due to fatigue. Fatigue establishes crack initiation and propagation and, therefore, the failure of the solder joint.

The most common failure mechanism in welded joints, according to the literature, is caused by cracks that are fundamentally a low-cycle fatigue mechanism, and follows the Coffin-Manson model (Brito 2014).

Thermal cycling in which the materials that make up the solar panel are exposed in space produces expansion and contraction of the materials, causing fatigue and, consequently, failures in the welded joints of the interconnects due to differences in the thermal expansion coefficients of the welded materials (Ferro et al. 1997), this directly affects the reliability of the solar panel during its operational phase. According to Gierth et al. (2012), the main factor contributing to the failures that occur in orbit is due to the thermal expansion that occurs between the solar cell material and the interconnection between them. According to 
Brennan et al. (1994), the failure of welded joints in solar cell interconnections may compromise or even incapacitate the solar panel to supply power to the satellite or spacecraft subsystems of which they are part.

\section{Design of Experiments}

According to Montgomery (2017), design of experiments (DoE) refers to the process of planning the experiments, which were collected and analyzed using statistical methods to provide objective and valid conclusions. The statistical approach to experimental design is necessary when one wishes to draw meaningful conclusions from the obtained data.

Figure 2 represents the process as a combination of operations, machines, methods, people, or other resources that turn some inputs into outputs that have one or more observed response variables. Some of the process factors are controllable, while others are uncontrollable or noisy (for example, the interaction between the factors).

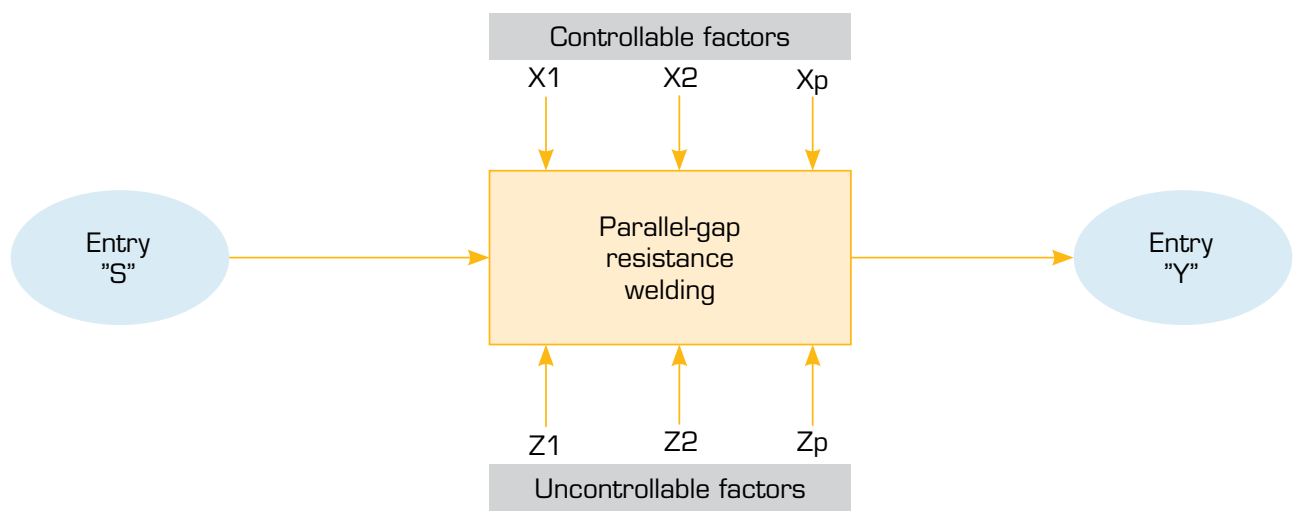

Figure 2. Process to parallel-gap resistance welding. Adapted from: Maia et al. (2019).

Some terms were defined for a better understanding of the design of experiment technique:

Control factors are factors that can be intentionally changed in the experiment in order to evaluate the effects caused on the response variables; and then, allow determining the main factors of the process (Galdámez and Carpinetti 2002).

Response variables are the parameters that suffer some effect in the experiment, when changes are intentionally caused in the factors that control machines in manufacturing processes. In experiments, the variables can be one or more responses that are important to evaluate (Galdámez and Carpinetti 2002).

Uncontrollable factors are factors that cannot be intentionally changed in the experiment, but cause effects on the response variables. For example, interactions between controllable factors, also called noise by some authors; according to Montgomery (2017), it can also be environmental conditions or material properties.

Factor levels are the operating conditions of the process or system control factors. When the tests are carried out, the optimal levels of the control factor or the value closest to that specified by the designers are determined (Galdámez and Carpinetti 2002).

\section{Guidelines for designing of experiments}

Figure 3 shows the guidelines applied in design of experiments according to Montgomery (2017). Each step of the guideline is described below.

The first step is the recognition and statement of problem, according to Montgomery (2017), that is to analyze the spot-welding process by electrical resistance used in solar cell interconnections through the technique of analysis and design of experiments.

The selection of the response variable, according to the literature shown in Table 1, as well as the AIAA (2014) standard to assess the influence of input factors in the welding process, is the tensile strength test. However, it is known that there are other means of evaluation; however, with a higher cost and a greater demand for human, financial and infrastructure resources (such as: analysis of the nugget welding by means of ultrasound or microscopy testing, nugget welding sizing etc.). 


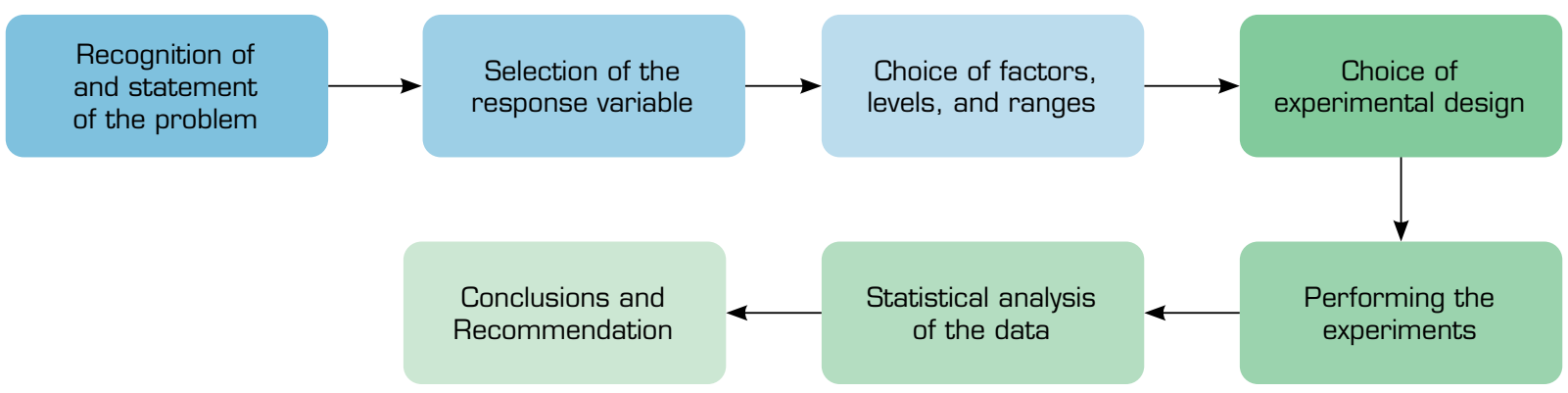

Figure 3. Guidelines for designing of experiments. Montgomery (2017).

Choice of factors, levels, and ranges: the definition of the factors for this work was first carried out by consulting the technical literature (Table 1).

Choice of experimental design. The complete factorial planning, according to Colombari (2004), Souza et al. (2013) and Montgomery (2017), is an experimental technique that consists of carrying out an experiment with $k$ factors, each of these factors being composed of two levels (for example: high and low or lower and higher). It is at this stage that tests are carried out with all possible combinations of preestablished levels of factors.

According to Maciel Junior (2011), the factorial method establishes an optimal model within the levels established for the variables, but there is no guarantee that the specified levels are in the ideal region of operation; therefore, the optimum location may differ from the global optimum. To guarantee a better performance in the process under study, the response surface methodology can be an alternative.

For a better understanding of the complete factorial planning, a statistical model for a factorial experiment $2^{2}$ is presented in Eq. 1. This can be used as an example for carrying out experiments with as many factors as necessary (Montgomery 2017). However, it is worth mentioning that a large number of factors make the technique unfeasible, since a greater number of experiments is necessary.

$$
y=k+k_{1} x_{1}+k_{2} x_{2}+k_{3} x_{1} x_{2}
$$

where: $k$ is constant; $k_{1}$ is control factor coefficient $x_{1} ; x_{1}$ is first control factor; $k_{2}$ is control factor coefficient $x_{2} ; x_{2}$ is second control factor; $k_{3}$ is coefficient of interaction between factors $x_{1} x_{2} ; x_{1} x_{2}$ is interaction between the first and the second control factor.

Experimental matrix. An experiment containing $k=4$ factors for a complete factorial is presented in Eq. 2, the calculation performed to determine the number of tests according to the complete factorial technique.

$$
2^{\mathrm{k}}=2^{4}=16 \text { tests }
$$

Table 2 shows a generic experimental matrix, showing 4 factors A, B, C and D, with the combination of minimum and maximum levels. In this table, -1 represents the minimum factor value, and 1 the maximum value.

For this research, the factor $\mathrm{A}$ is the electrode force; factor $\mathrm{B}$ is welding voltage; factor $\mathrm{C}$ is welding time and the factor $\mathrm{D}$ is the charge.

According to Souza et al. (2013), the experimental matrix is a way to show all possible combinations of the process parameters and their respective levels. 
Table 2. Generic experimental matrix with factors A, B, C and D.

\begin{tabular}{ccccc}
\hline Test. No & Factor A & Factor B & Factor C & Factor D \\
\hline 1 & -1 & -1 & -1 & -1 \\
3 & 1 & -1 & -1 & -1 \\
4 & -1 & 1 & -1 & -1 \\
5 & 1 & 1 & -1 & -1 \\
6 & -1 & -1 & 1 & -1 \\
7 & 1 & -1 & 1 & -1 \\
8 & -1 & 1 & 1 & -1 \\
9 & 1 & 1 & 1 & -1 \\
10 & -1 & -1 & -1 & 1 \\
11 & 1 & -1 & -1 & 1 \\
12 & -1 & 1 & -1 & 1 \\
13 & 1 & 1 & -1 & 1 \\
14 & -1 & -1 & 1 & 1 \\
15 & 1 & -1 & 1 & 1 \\
16 & -1 & 1 & 1 & 1 \\
\hline & 1 & 1 & 1 & 1 \\
\hline
\end{tabular}

\section{METHODOLOGY}

For this experiment, 36 samples from database was used, that is, four input factors: force of application of the electrode on the part [given in number of steps of the stepper motor]; welding voltage [mV]; welding time [ms]; and charge [in unit of As] were analyzed. The response variable used was the pull test (given in $\mathrm{N}$ ).

Figure 4 shows the methodology adopted for this work based in guidelines for designing of experiments.

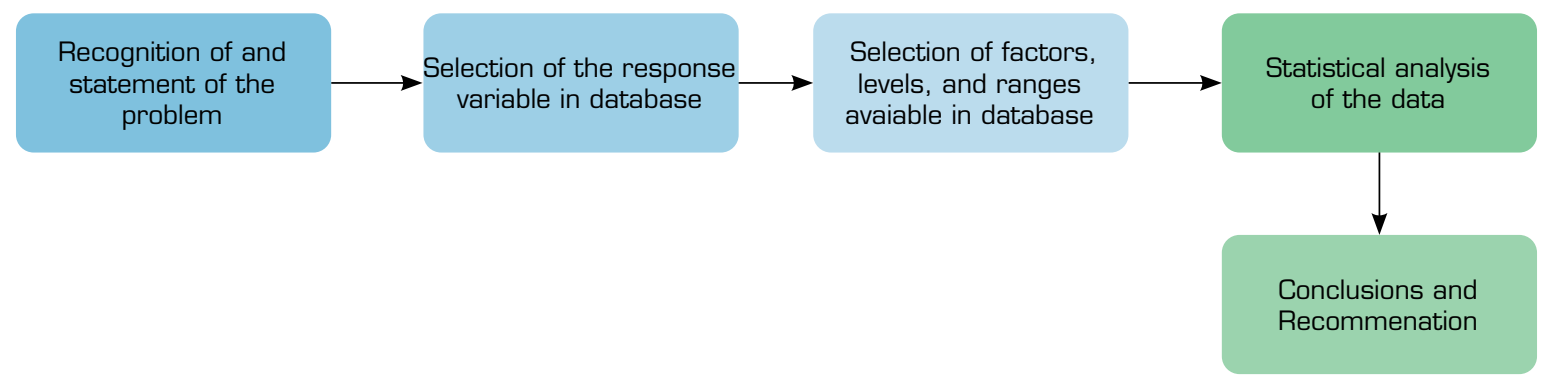

Figure 4. Methodology for this work.

For this work the values of the welding parameters were not revealed in order to preserve the confidentiality of the company's data.

Table 3 presents the pull test values for 36 samples. These values were obtained through a device that pulls the sample at 0 degrees in relation to the welded joint, with a speed of $2 \mathrm{~mm} / \mathrm{min}$. The pull test values were measured in grams in the device and converted to Newton in the table below. 
Table 3. Pull test values for 36 samples.

\begin{tabular}{cccccc}
\hline Test. No & Pull test $(\mathbf{N})$ & Test. No & Pull test $(\mathbf{N})$ & Test. No & Pull test (N) \\
\hline 1 & 1.5 & 13 & 0.9 & 25 & 1.4 \\
2 & 1.5 & 14 & 1.1 & 26 & 1.6 \\
3 & 1.4 & 15 & 1.4 & 27 & 1.5 \\
4 & 1.4 & 16 & 1.7 & 28 & 1.5 \\
5 & 1.2 & 17 & 1.5 & 29 & 1.5 \\
6 & 1.4 & 18 & 1.9 & 30 & 1.8 \\
7 & 1.4 & 19 & 1.9 & 31 & 1.8 \\
8 & 1.4 & 20 & 1.8 & 32 & 2.6 \\
9 & 1.6 & 21 & 1.5 & 33 & 1.5 \\
10 & 1.2 & 22 & 1.4 & 34 & 1.5 \\
11 & 1.3 & 23 & 1.4 & 35 & 1.5 \\
12 & 1.1 & 24 & 1.2 & 36 & 1.6 \\
\hline
\end{tabular}

\section{RESULTS AND DISCUSSION}

According to the methodology presented in Fig. 4, the information regarding the welding process was collected in the database and analyzed with the aid of the Minitab 17 software.

The Pareto chart shows the absolute values of the standardized effects from the largest effect to the smallest effect. The standardized effects are t-statistics that test the null hypothesis that the effect is zero. The chart also plots a reference line to indicate which effects are statistically significant.

The Pareto chart shows the values of the standardized effects from the highest to the lowest effect. This plot is represented in Fig. 5, where it is possible to verify the most significant factors for the response variable (pull test). It is possible to verify that the welding time and charge are the most prominent factors; however, they do not exceed the red line that highlights the significant factors.

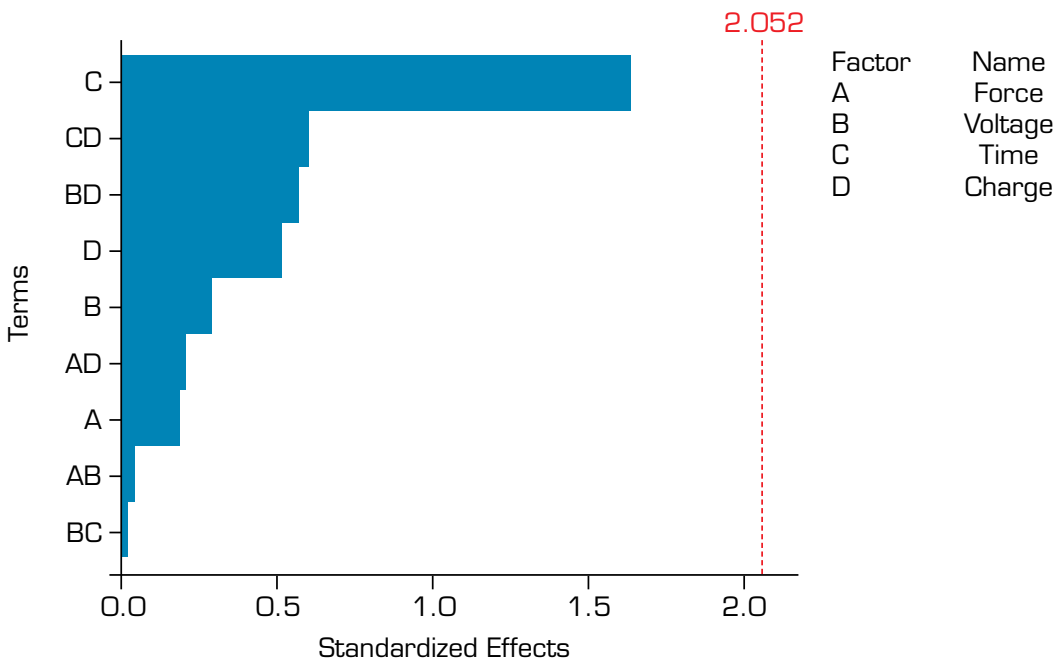

Figure 5. Pareto chart of the standardized effects. Response is Pull Test, $\alpha=0.05$ 
In Fig. 5, the parameters that pass the red line are statistically significant at the 0.05 level with the terms of the current model, and the term $\mathrm{CD}$ is an interaction of factors $\mathrm{C}$ and $\mathrm{D}$ as well as $\mathrm{BD}$ is an interaction of factors $\mathrm{B}$ and $\mathrm{D}$ and so on. If some adjustments are made to the model, the Pareto chart will show only the significant factors, using the regression elimination method, where all factors are included in the initial analysis and then the nonsignificant factors are removed one by one.

Applying the method above, it is noted that the effects of factors D (charge) and C (welding time) and the interaction BC (welding time versus voltage) stand out as the most significant factors and interaction, as can be seen in Fig. 6, where the parameters, that pass the red line are statistically significant at the 0.05 level with the terms of the current model. The third (for example ABC or $\mathrm{CDA}$ ) and fourth (for example $\mathrm{ABCD}$ ) order interactions between the factors were disregarded in the Pareto chart in Fig. 6.

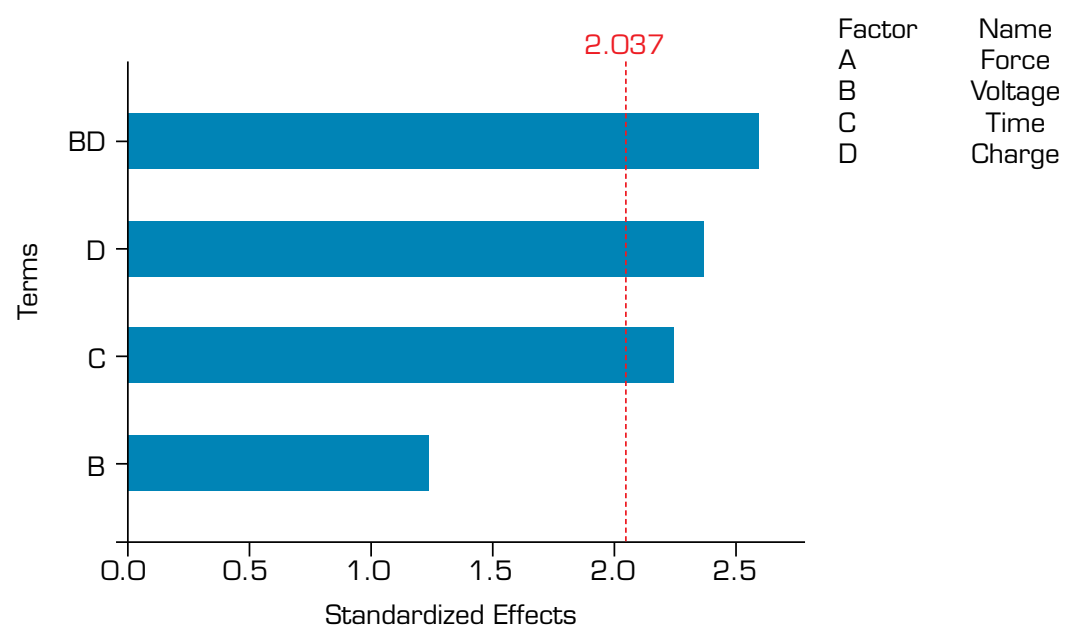

Figure 6. Pareto chart of the standardized effects. (Response is Pull Test, $\alpha=0.05$ )

The main effect plot for pull test as shown in Fig. 7 give the information about the effect of each parameter (factor control) on the response variable (pull test). A main effect is the difference in the mean response between two levels of a factor; the horizontal centerline shows the mean of the pull test for all parameters.

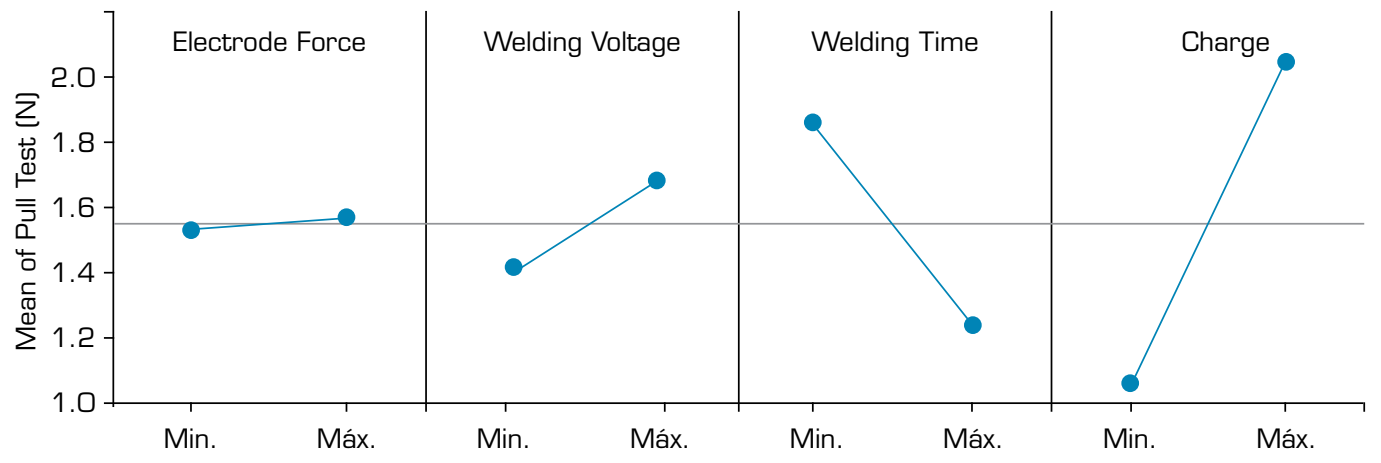

Figure 7. Main effects plot for pull test. Fitted means

The analysis of the plots shown in Fig. 7 is performed based on the variation that the change from the minimum to the maximum level promotes in the response variable; therefore, the greater the variation in the response, the more significant the factor under analysis.

Based on the statement above and on Fig. 7, it appears that charge and welding time are the factors that has the greatest significant effect on pull test. With a higher charge value, a higher pull test value is noted as well as for welding voltage in a smaller scale. 
The graphs presented in Fig. 8 show the average of the pull test value versus the interactions between the parameters. In this graph when a line is parallel to another, there is no interaction between the factors. When the lines are not parallel, there is a greater strength of the interaction.

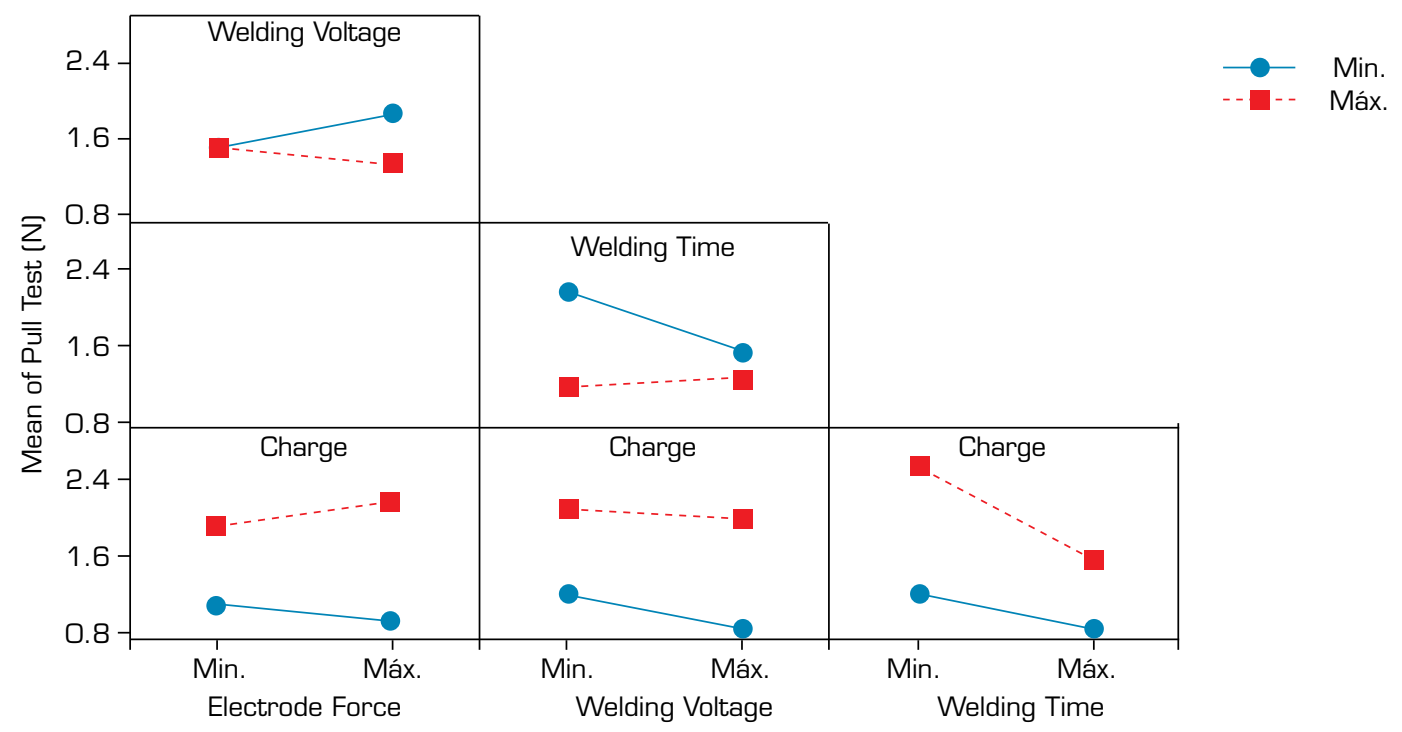

Figure 8. Interaction plot between parameters. Fitted means

For the first graph, there is the interaction between electrode force and welding voltage because the dashed red and blue continuous lines are not parallel. It is observed that when the welding voltage is kept at the minimum value (blue continuous line), the pull test value increases with the increment in the electrode force. On the other hand, when the welding voltage is kept at maximum value (red dashed line), the pull test value decreases with the increase in the electrode force. It is performed a similar analysis for the other graphs in Fig. 8 for the other factors.

\section{CONCLUSIONS}

An increase in charge causes an increase in pull test values; on the other hand, with an increase in the welding time, the pull test values tends to decrease, as well as for the welding voltage, however, on a smaller scale.

Using the design of the experiment and a database, it was possible to determine, among the four welding parameters, the most important for the process in question; that is, which ones actually had significant effects on pull test. With the aid of the Minitab 17 statistical analysis software, it was found that the most significant factors in these preliminary tests were the charge, the welding time and welding voltage.

Thus, the experiment design technique proved to be effective in a first analysis of the improvement of the welding process. The methodology was validated as an important tool to be considered when it is intended to reduce costs and the amount of resources to carry out experiments. The use of this tool aims to eliminate defects in manufactured products, in addition to providing a better understanding of the relationship between the factors involved in the process.

It is intended to continue this work aiming at the optimization of the welding process with the use of new experiments based on a planned experimental matrix, in addition to the response surface methodology. For this, additional experiments will be necessary. 


\section{AUTHORS' CONTRIBUTION}

Conceptualization: Souza MLO; Formal Analysis: Maia GFS; Methodology: Brito AC; Original Draft: Maia GFS; Supervision: Souza MLO and Brito AC.

\section{DATA AVAILABILITY STATEMENT}

All the datasets were generated and analyzed during the current study.

\section{FUNDING}

This research received no specific grant from any funding agency in the public, commercial, or not-for-profit sectors.

\section{ACKNOWLEDGEMENTS}

To the Organization Committee of II Congresso Aeroespacial Brasileiro to the Instituto Nacional de Pesquisas Espaciais and to Engenharia Orbital.

\section{REFERENCES}

[AIAA] American Institute of Aeronautics and Astronautics (2014) Standard: Qualification and Quality Requirements for Space Solar Cells. Reston: AIAA. https://doi.org/10.2514/4.102806.001

Abrahão ABRM, Reis JF, Brejão SD, Ribeiro VG, Costa ML, Botelho EC (2015) Avaliação dos parâmetros tempo, corrente e pressão na soldagem por resistência elétrica de compósitos PEI/fibras contínuas: influência na resistência mecânica. Matéria 20(2):530-543. https://doi.org/10.1590/S1517-707620150002.0053

Amaral FF, Almeida FA, Costa SC, Leme RC, Paiva AP (2018) Aplicação da Metodologia de Superfície de Resposta para Otimização do Processo de Solda a Ponto no Aço Galvanizado AISI 1006. Soldag Insp. 23(2):129-142. https://doi. org/10.1590/0104-9224/si2302.02

An R, Xu D, Wang C (2014) Parallel-gap resistance welding between gold-plated silver interconnects and silver electrodes in germanium solar cells. Paper presented 15th International Conference on Electronic Packaging Technology. IEEE; Chengdu, China. https://doi.org/10.1109/ICEPT.2014.6922812

Atashparva M, Hamedi M (2018) Investigating mechanical properties of small scale resistance spot welding of a nickel based superalloy through statistical DOE. Exp Tech 42(1):27-43. https://doi.org/10.1007/s40799-017-0221-2

Aures JEV (2006) Estudo da formação, geometria e resistência do ponto na soldagem por resistência: uma abordagem estatística (Master thesis). Brasília: Universidade de Brasília. In Portuguese.

Avila TLD, Bracarense AQ (2017) Influência dos parâmetros de soldagem no ensaio de torção de solda a ponto em um dispositivo automatizado recém desenvolvido. Soldag Insp 22(2):228-237. https://doi.org/10.1590/0104$9224 / \operatorname{si2} 202.11$ 
Baruel MF (2012) Estudo da variação da corrente fotogerada nos painéis solares dos satélites do INPE (Master thesis). São José dos Campos: Instituto Nacional de Pesquisas Espaciais. In Portuguese.

Brennan PC, Jamieson RA, Garcia A, Malachesky PA, Simburger EJ (1994) Evaluation of welded interconnects on thermally cycled silicon solar cells. Paper presented Proceedings of 1994 IEEE 1st World Conference on Photovoltaic Energy Conversion - WCPEC (A Joint Conference of PVSC, PVSEC and PSEC). IEEE; Waikoloa Village, Hawaii, United States. https://doi. org/10.1109/WCPEC.1994.520767

Brito AC (2014) Comparação experimental de técnicas de regressão linear para análise da confiabilidade dos empacotamentos CBGA submetidos à ciclagem térmica e proposta de um novo método para o ajuste e a predição de suas falhas (Doctoral thesis). São José dos Campos: Instituto Nacional de Pesquisas Espaciais. In Portuguese.

Callister Junior WD (2008) Ciência e engenharia dos materiais: Uma introdução. Rio de Janeiro: LTC.

Carneiro MRD, Barbosa RH (2015) Estudo dos parâmetros de solda a ponto com ênfase na soldagem de aços galvanizados. Campos dos Goytacazes: Instituto Federal de Educação.

Colombari RR (2004) Aplicação de delineamento de experimentos para o processo de solda à projeção (Master thesis). Itajubá: Universidade Federal de Itajubá. In Portuguese.

Dias JS (2011) Uma metodologia para otimização de parâmetros de soldagem através de solda por resistência aplicada a chapa de aço "Interstitial Free" IF (Master dissertation). Rio de Janeiro: Centro Federal de Educação Tecnológica. In Portuguese.

Ferro RJ, Francis RW, Frasco EB, Pan RB, Pierre-Louis E, Sve C, Berghaus M (1997) Novel techniques for evaluation of interconnections in solar cells used for spacecraft power generation. Paper presented Conference Record of the Twenty Sixth IEEE Photovoltaic Specialists Conference - 1997. IEEE; Anaheim, California, United States. https://doi.org/10.1109/PVSC.1997.654246

Galdámez EVC, Carpinetti LCR (2002) Aplicação das técnicas de planejamento e análise de experimentos no processo de fabricação de produtos plásticos.

Gierth P, Rebenklau L, Michaelis A (2012) Evaluation of soldering processes for high efficiency solar cells. Paper presented 35th International Spring Seminar on Electronics Technology. IEEE; Bad Aussee, Austria. https://doi.org/10.1109/ ISSE.2012.6273123

Maciel Junior H (2011) Uso do planejamento e análise de experimentos no desenvolvimento de um processo de solda por resistência elétrica de pequena escala (Master thesis). Itajubá: Universidade Federal de Itajubá. In Portuguese.

Kim T, Park H, Rhee S (2007) Optimization of welding parameters for resistance spot welding of TRIP steel with response surface methodology. Int J Prod Res 43(21):4643-4657. https://doi.org/10.1080/00207540500137365

Liu J (2017) A study on the influence factors of parallel-gap welding heat. Paper presented 18th International Conference on Electronic Packaging Technology (ICEPT). IEEE; Harbin, China. https://doi.org/10.1109/ICEPT.2017.8046625

Maia GFS, Brito AC, Souza MLO (2019) Análise preliminar dos parâmetros e interações do processo de soldagem de interconexões entre células solares empregando projeto de experimentos visando sua futura otimização. Paper presented Anais do $2^{\circ}$ Congresso Aeroespacial Brasileiro. CAB; Santa Maria, Rio Grande do Sul, Brazil. https://doi. org/10.29327/2cab2019.224917

Miller (2010) Handbook for resistance spot welding. [accessed May 24 2018]. https://www.millerwelds.com/-/media/ millerwelding

Montgomery DC (2017) Design and analysis of experiments. Hoboken: John Wiley \& Sons. 
Muhammad N, Manurung YHP, Hafidzi M, Abas SK, Tham G, Haruman E (2012) Optimization and modeling of spot welding parameters with simultaneous multiple response consideration using multi-objective Taguchi method and RSM. J Mech Sci Technol 26(8):2365-2370. https://doi.org/10.1007/s12206-012-0618-X

O’Connor PDT, Kleyner A (2012) Practical reliability engineering. Hoboken: John Wiley \& Sons.

Rauschenbach HS (1980) Solar cell array design handbook: The principles and technology of photovoltaic energy conversion. Dordrecht: Springer. https://doi.org/10.1007/978-94-011-7915-7

Santos WA (2013) Estudo da influência dos parâmetros de regulagem na soldagem por resistência na indústria automobilística (Monography). São Caetano do Sul: Instituto Mauá de Tecnologia. In Portuguese.

Santos CES, Maia GFS, Souza MLO, Rabello APSS (2019) Uma discussão sobre combinar análises da física da falha e até dados de campo a métodos tradicionais para melhorar as predições da confiabilidade de equipamentos eletrônicos. Paper presented Congresso e Mostra Internacionais SAE Brasil de Tecnologia da Mobilidade. São Paulo, São Paulo, Brazil.

Souza MTS, Fernandes MM, Miranda RC (2013) Otimização dos parâmetros de soldagem a ponto por resistência em uma indústria automotiva por meio da análise de experimentos e metodologia de superfície de resposta. Ciência \& Engenharia 22(2):131-140. https://doi.org/10.14393/19834071.2013.20995

Steinmeier D (2010) Resistance welding - parallel gap welding basics: micro joining solutions - microTipsTM. Arcadia: CA 91007.

Valera J, Miguel V, Martínez A, Naranjo J, Cañas M (2017) Optimization of electrical parameters in Resistance Spot Welding of dissimilar joints of micro-alloyed steels TRIP sheets. Procedia Manuf 13:291-298. https://doi.org/10.1016/j. promfg.2017.09.074

Vaz CC (1999) Geradores fotovoltaicos: apresentação do curso de tecnologia de satélites (class notes). São José dos Campos: Instituto Nacional de Pesquisas Espaciais. In Portuguese.

Vaz CC, Vaz JV (2007) Manufacturing and testing of the electrical part of solar array for the China-Brazil Earth Resource Satellite - CBERS 2B. Paper presented 19th International Congress of Mechanical Engineering. ABCM; Brasília, Distrito Federal, Brazil.

Wiese S; Meier R, Kraemer F (2010) Mechanical behavior and fatigue of copper ribbons used as solar cell interconnectors. Paper presented 2010 11th International Thermal, Mechanical \& Multi-Physics Simulation, and Experiments in Microelectronics and Microsystems (EuroSimE). IEEE; Bordeaux, France. https://doi.org/10.1109/ESIME.2010.5464551

Yue XK, Tong GQ, Chen F, Ma XL, Gao XP (2017) Optimal welding parameters for small-scale resistance spot welding with response surface methodology. Sci Technol Weld Join 22(2):143-149. https://doi.org/10.1080/13621718.2016.1204799 